\title{
MACROECONOMIC DETERMINANTS OF NON-PERFORMING LOANS (NPL): EVIDENCE FROM PAKISTAN
}

\author{
ALTAF HUSSAIN \\ Lecturer in Economics, \\ The Islamia University of Bahawalpur, Pakistan, \\ Bahawalnagar Campus. \\ Email: altafhussain@iub.edu.pk \\ AMBAR KHALIL \\ Research Scholar of Economics, \\ The Islamia University of Bahawalpur, Pakistan, \\ Bahawalnagar Campus. \\ Email: amberkhalil70@gmail.com \\ MARYAM NAWAZ \\ M. Phil. Scholar of Economics, \\ National College of Business Administration \& Economics, Lahore. \\ Multan Campus \\ Email: maryamnawaz563@gmail.com
}

\begin{abstract}
This analytical study investigates the determinants of non-performing loan in Pakistan. Secondary data is used in this study. The data is collected through World Bank Databank, international financial statistics and various issues of economic survey of Pakistan. The issue of Non-Performing Loan is one of the clusters of financial problems in Pakistan. No one can deny the importance of financial sector in any economy. In this study we find the macroeconomic factor that surge the NPL. We also suggest some strategies to cutback the nonperforming loans. Current study uses the time series data of Pakistan, ranging from 1990 to 2013. Ordinary least square (OLS) method is used to investigate the problem. The dependent variable is non-performing loan and independent variables are exchange rate, interest rate, GDP, share prices, energy crisis, exchange rate and energy crisis. GDP has significant relationship with NPL and interest rate, share prices have insignificant relationships with NPL. A positive link has established between non-performing loans and various independent variables like energy crisis, exchange rate, interest rate, share prices. But on the other hand a negative relationship has been found between dependent variable and GDP.
\end{abstract}

Keywords: Macroeconomics, Financial Economics, Multiple Regression.

JEL Classification Codes: B22, B26, C24, E58 


\section{INTRODUCTION}

For a long time, accumulation of physical capital has been emphasized by development economist in order to prosper economically. This can be better understand by "classical and neo classical growth theories". In contemporary era along with accumulation of physical capital, investment in human capital is buzz word in developmental studies.

How can a country invest in both physical and human capital on the same time so that to bet balance between them? Answer to this question relies on the responsibilities of both public and private sectors of the concerned country. And this balanced piece of investment in physical and human capital can only be targeted if sufficient funds are available in the economy. But this is not the case always; adequate funds are harder to be available. Here comes the role of sound financial sector to channelize the surplus funds from savers to investors.

Significance of financial sector in any country (developed or developing) can never be neglected; these financial institutes augment the productivity of real sector by directing the surplus funds towards most productive investments (Richard, 2011). Tremendous performance of these financial institutions is the symbol of prosperity and economic growth in the country or region and on the other hand poor performance of these institutions not only hamper the economic growth of the particular region but also affects the economic fabric of the whole world (Khan and Senhadji, 2001). In the last few decades we can see many banking failures in all over the world (Brown Bridge and Harvey, 1998) and due to these banking failures many banks have been closed by regulatory authorities (Brown Bridge, 1998). According to Brown Bridge, (1998) many empirical researches have shown that most of the time banking failures or banking crisis are caused by nonperforming loans.

Non-performing Loans (NPL) have gained researchers' intention in the last three to four decades all over the world as banking crisis which are turning into banking failures are because of these mounting non-performing loans (Barr and Siems, 1994). Nonperforming loans are one of the main reasons that cause insolvency of the financial institutions and eventually wound the whole economy (Hou, 2007). By pondering upon these facts it is essential to overcome non-performing loans for the economic growth in the country, otherwise the resources can be jammed in unprofitable projects and sectors which 
not only damage the financial stability but also hamper the economic growth. In order to regulate the non-performing loans, it is needed to understand the roots of these nonperforming loans in the particular financial sector.

As for as Pakistan is concerned, total non-performing loans was amounting to PKR 613 billion for entire banking system of the country as per data delivered by state bank of Pakistan on June 30, 2013 out of which PKR 507 billion was in loss category.

Non-performing loans in Pakistan were comparatively lower in 2000 as for as Bangladesh, India and China is concerned. But after 2006, upward trend in NPL has been observed and consequently from 2007 to 2012 NPL are showing opposite picture meaning that non-performing ratio (NPL to gross loans) is $14.8 \%$ which is higher than respective ratio in Bangladesh, India and China.

The existing literature proves that loan quality in terms of non-performing loans to gross loans depends upon macroeconomic indicators as well as bank specific determinants. The deteriorative loan quality can lead to massive banking crisis which is also evident from the previous researches. This is a latest study on the issue with an objective to investigate into the macroeconomic indicators of non-performing loans in Pakistan.

This paper is organized in different sections; first section provided an introduction to subject matter of the study. Second section reviews the previous relevant studies and in third section methodology adopted to analyses the issue of non-performing loans is discussed. Fourth section discusses the results of the study. Fifth section concludes the whole study while references are given in last section.

\section{LITERATURE REVIEW}

Ghosh (2007) investigated the relationship between financial liberalization and problem loans in Indian banking sector. To do so, annual data over the period of 19962000 , on some macro and micro variables, for state owned banks was used. Generalized method of moment (GMM) estimation showed that liberalization improved the health of loans. And rapid growth of loans and decline in the capital of banks also worsen the quality of loans in Indian banking sector.

Bebczuk and Sangiacomo (2008) used the annual cross sectional data (19982005) to investigate the determinants of nonperforming loan in argentine banking system. 
Econometric results of the study showed that non-performing loan increased when economy faced the recession and also when time borrower faced the many problems due to which cannot repay the amount of loan so bank cannot give the amount of loan when economy at boom. The study also identified indebtedness, borrower size, bank structure and type of loan as major determinants of non-performing loans.

Masood \& Aktan (2009) used primary data collected through questionnaire from 100 credit managers of Turkish and 110 from Pakistani banking sectors. The ordered probit models were employed for empirical analysis. the determinants of nonperforming loan and also shown that communication faculties provided to credit managers .Senior management is responsible for non-performing loan in Pakistan there need to improve the credit managers, if credit managers give the loan to right person then that come back soon otherwise that change into bad debt Basic education, professional education, year of services, number of course attended by credit managers, credit limit are negatively related to the non-performing loan.

Festic, Kavklor and Repina (2010) analyzed the impact of macroeconomic and banking sector variables on non-performing loans as indicator of quality of loans in Baltic States. A panel data for the period of 1995:01 to 2009:02 was used for panel data regressing analysis. The results of fixed and random effect models conclude that improvements in gross fixed capital formation and export oriented industries in the states decelerate the level of NPL but on the other hand higher growth rates (GDP) contribute in mounting the NPL due to overheating of the economies.

Abedola, Wan Yusoff and Dalahan (2011) attempted to explore the macroeconomic reasons of non-performing loans in Islamic banking system of Malaysia. ARDL bound test approach along with Granger causality test was applied on monthly data over the period of 2007:01 to 2009:12 and finally base on the study, it was inferred that interest rate and industrial production index have positive and long run effect on NPL but producer price index has negative and significant impact on NPL.

Shrestha (2011) sampled the 18 Nepalese banks to know how NPL contribute to stock prices of the banking sector. Simple linear regression model was estimated and a negative relationship was established between stock prices and non-performing loans in banking sector of Nepal. 
Nkusu (2011) used the panel autoregressive (PVAR) model and impulse response function (IRF's) and identified the macroeconomic determinants of NPL in 26 developed countries over the period of 1998 to 2009. Adverse economic condition in terms of low GDP and high unemployment affected the NPL, and this was deduced that this worse quality of NPL contributed to financial crisis.

Ahmad, Alias, Asrari and Ahmad (2011) analyzed the effects of interest rate and inflation on non-performing loans in Malaysia for the period of January 2006 to December 2009. Results vector error correction model (VECM) were estimated by using Johansen and Juselius method for co-integration and concluded that no significant relationship exist between the independent and dependent variables. But on the other hand, in the long-run interest rates influences the NPL negatively and significantly. At the same time inflation have the positive relationship with NPL, as far as the economy of Malaysia is concerned.

Louzis, Vouldis and Metaxas (2012) took the dynamic panel data for the period of 1980-2009 to investigate the macroeconomic and bank specific variable having an influence on the loan quality in Greece. The generalized method of moments (GMM) approach was used for practical investigation of the issue. The study concluded that macroeconomic variables, especially the real GDP growth rate, unemployment rate, lending rate, have solid effect on the non-performing loan but effect may vary amongst different categories of loans.

Farhan, Sattar, Chaudhry and Khalil (2012) used the cross sectional primary data to investigate the perceptions about economic determinants of loan. For this purpose, ten banks from Pakistan were selected for data collection. Correlation and regression analysis were used for this perception based study. Hence, study concluded that explanatory variable such as interest rate, energy crisis, unemployment, and inflation has positive relationship with non-performing loan while GDP growth has negative relationship with nonperforming loan. This was also discussed in the study that energy crisis has badly affected the banking sector and consequently banking sector faced a loss due to non-performing loan.

Moinescu and Codirlaşu (2012) estimated the SUR system of simultaneous equations and VAR model to identify the impact of real and monetary sectors of Romanian economy's sectoral non-performing loans over the period of 2004:Q3 to 2010:Q1. The 
study concluded that FDI affected the NPL negatively in industrial sector but exchange rate deteriorated the NPL in services and construction sector of the economy.

Ahmad and Bashir (2013) used the times series data over the period 1990 to 2011 to investigate the supremacy of macroeconomic variable as determinants of nonperforming loan. Ordinary Least Square (OLS) was employed for empirical investigation. They found GDP, inflation, local currency export industrial production and foreign direct investment having a negative relationship with the nonperforming loan. But unemployment, interest rate and $\mathrm{CPI}$ have positive relationship with the non-performing loan.

Badar and Javid (2013) assessed the influence of macroeconomic indicators on non-performing loans for the period covering January 2002 to December 2011. Granger causality test and co-integration technique was employed on quarterly data and concluded that inflation and exchange rate granger caused the non-performing loans. Moreover, a weak short-run relationship also found between these variables.

For Italy, Greece and Spain reasons for non-performing loans were detected by Messai and Jouini (2013). Effect of bank specific variables of 85 banks on NPL was estimated along these macroeconomic variables such as GDP growth, real interest rates and unemployment rate were also taken as independent variables. Result of panel data for the period 2004-2008 showed a negative relationship between NPL and GDP growth rate but positive relation was identified as unemployment concerned.

Based on the review of previous available literature on NPL suggests that there is major role of macroeconomic variables in status of non-performing loans in almost all countries either developed or developing.

\section{DATA AND METHODOLOGY}

\section{A. DATA AND METHODS}

In order to find out the macroeconomic determinants of non-performing loans in Pakistan, quarterly time series data on some selected variables for the period of 1990:01 to 2013:02 is used. Data on dependent variable (non-performing loans) and independent variables, such as economic growth, energy crisis, exchange rate, share prices and interest rates, is taken from Handbook of Statistics published by State Bank of Pakistan, Economic Survey of Pakistan by Ministry of Finance, World Development Indicators (WDI) released 
by World Bank (WB) and International Financial Statistics (IFS) published by International Monetary Fund (IMF). Econometric results are estimated by multiple regression model. Ordinary Least Square Method (OLS) is employed to estimate the model and a few diagnostics statistics are also utilized to check the reliability of the model.

\section{B. MODEL SPECIFICATION}

The econometric model to be estimated in order to achieve objective of the study is as follows:

$$
N P L_{t}=a+\beta_{1} E C_{t}+\beta_{2} E R_{t}+\beta_{3} G D P_{t}+\beta_{4} I R_{t}+\beta_{5} S P_{t}+\beta_{6} N P L_{t-1}+\varepsilon
$$

Where;

$\alpha$ is intercept and $\beta_{1}$ through $\beta_{6}$ are slope coefficients for repressors.

$\mathrm{NPL}=$ Non-performing Loans

$\mathrm{EC} \quad=$ Energy Crisis

ER = Exchange Rate

GDP $=$ Gross Domestic Product

IR = Interest Rate

$\mathrm{SP} \quad=$ Stock Prices

$\mathrm{NPL}_{\mathrm{t}-1}=$ Non-performing Loans in Lagged Year

Theoretically and practically intuition suggest that last year's non-performing loan can also be the reason of current year's NPL. This is the logic to include the lagged value of NPL as independent variable in the model.

\section{VARIABLE DESCRIPTION}

\section{NON-PERFORMING LOANS}

According to State Bank of Pakistan (SBP), if principal or mark-up repayments of a loan are overdue for 90 days after a due date then that loan is considered as nonperforming loan. In this study loan-performing ratio calculated as total amount of nonperforming loans to gross loans of banking system is taken as proxy of non-performing loans or loan quality. 


\section{ECONOMIC GROWTH}

Economic growth is measured as annual percentage increase or decrease in gross domestic product of Pakistan.

\section{ENERGY CRISIS}

It is the difference between energy demand and energy supply from different energy sources after converting it into kilo tons of oil equivalent as an aggregate measure of energy crisis.

\section{EXCHANGE RATE}

Annual average conversion rate from Pakistan Rupee to US Doller is used.

\section{SHARES' PRICES}

KSE-100 Index is uses as proxy of variation in shares' prices.

\section{INTEREST RATE}

Call money rate, which is a rate on banks' loan made to brokerage firms to fund their clients, is taken as proxy of interest rates.

Table-1 gives a summary of variables, their measurements, and expected relationships and data sources.

Table 1: Description of Variables and their Measurement

\begin{tabular}{|c|c|c|c|c|}
\hline Variables & $\begin{array}{l}\text { Symbolic } \\
\text { form }\end{array}$ & $\begin{array}{c}\text { Unit of } \\
\text { measurement }\end{array}$ & $\begin{array}{c}\text { Data } \\
\text { sources }\end{array}$ & $\begin{array}{l}\text { Expected } \\
\text { relationship }\end{array}$ \\
\hline $\begin{array}{l}\text { Non- } \\
\text { performing } \\
\text { Loans }\end{array}$ & NPL & $\begin{array}{l}\text { Ratio of NPL to } \\
\text { Gross Loans }\end{array}$ & $\begin{array}{l}\text { Handbook of } \\
\text { Statistics } \\
\text { (SBP) }\end{array}$ & Dependent Variable \\
\hline Energy Crisis & EC & $\begin{array}{c}\text { Kilo Tons of Oil } \\
\text { Equivalent }\end{array}$ & WDI (WB) & Positive \\
\hline $\begin{array}{l}\text { Exchange } \\
\text { Rate }\end{array}$ & ER & $\mathrm{PKR} / 1 \$$ & WDI (WB) & Positive \\
\hline $\begin{array}{c}\text { Gross } \\
\text { Domestic } \\
\text { Product }\end{array}$ & GDP & Million PKR & WDI (WB) & Negative \\
\hline $\begin{array}{c}\text { Shares' } \\
\text { Prices }\end{array}$ & SP & $\begin{array}{c}\uparrow \downarrow \mathrm{KSE}-100 \\
\text { INDEX }\end{array}$ & IFS (IMF) & Negative \\
\hline $\begin{array}{c}\text { Interest } \\
\text { Rates }\end{array}$ & IR & $\begin{array}{c}\text { Quarterly Rate } \\
\text { on Call Money } \\
\text { Loans }\end{array}$ & IFS (IMF) & Positive \\
\hline $\begin{array}{l}\text { Lagged Non- } \\
\text { performing } \\
\text { Loans }\end{array}$ & NPL(-1) & $\begin{array}{l}\text { Ratio of NPL to } \\
\text { Gross Loans of } \\
\text { Previous Year }\end{array}$ & $\begin{array}{l}\text { Handbook of } \\
\text { Statistics } \\
\text { (SBP) }\end{array}$ & Positive \\
\hline
\end{tabular}




\section{RESULTS AND DISCUSSION}

Following the quantitative and empirical research design, descriptive statistics and Ordinary Least Square (OLS) regression have been used to estimate the impact of most influential macroeconomic variables on amount of non-performing loans in Pakistan. As far as OLS is concerned, we also used some diagnostic statistics to check the overall health and predicting ability of the model to be estimated.

Table 2: OLS Regression Results for Model

\begin{tabular}{ccccccc}
\hline Measure & $\begin{array}{c}\text { Energy } \\
\text { Crisis }\end{array}$ & $\begin{array}{c}\text { Exchange } \\
\text { Rate }\end{array}$ & GDP & $\begin{array}{c}\text { Shares' } \\
\text { Prices }\end{array}$ & $\begin{array}{c}\text { Interest } \\
\text { Rate }\end{array}$ & $\begin{array}{c}\text { NPL } \\
\text { Ratio }\end{array}$ \\
\hline Mean & 56943.96 & 54.49 & 598334.70 & 5917.5 & 9.11 & 14.73 \\
\hline Median & 57092.51 & 57.97 & 422193.70 & 2435.5 & 9.04 & 14.47 \\
\hline $\begin{array}{c}\text { Standard } \\
\text { Deviation }\end{array}$ & 1.86 & 21.93 & 592635.42 & 5774.41 & 2.85 & 5.11 \\
\hline Kurtosis & -1.27 & -0.85 & 23.47 & 0.6918 & 0.865 & -1.17 \\
\hline Skewness & 0.055 & 0.26 & 3.98 & 1.1453 & -1.053 & 0.15 \\
\hline Range & 56735.93 & 77.59 & 4219888.90 & 24349.68 & 10.33 & 16.10 \\
\hline Minimum & 28108.64 & 21.52 & 56312.00 & 911.42 & 2.14 & 7.29 \\
\hline Maximum & 84844.56 & 99.11 & 592635.42 & 25261.10 & 12.47 & 23.4 \\
\hline Authors' own calculations based on the data from International Financial Statistics (IFS), IMF. \& WDI
\end{tabular}

In first step of this empirical research, descriptive statistics have been calculated (shown in table-2) which show that there is a variation in the data set and in its shape of distribution. Table 3 demonstrates the coefficients (slopes or rates of change in dependent variable due to a change in independent variable) of the macroeconomic variables taken in the multiple regression model.

Table 3: OLS Regression Results for Model

\begin{tabular}{lcccc}
\hline Variable & Coefficient & Std. Error & t-statistics & Prob. \\
\hline EC & 4.8203410 & 2.237010 & 2.154814239 & 0.0472 \\
\hline ER & 0.0077890 & 0.003524 & 2.210272418 & 0.0430 \\
\hline GDP & -0.049261 & 0.016374 & -3.00848906 & 0.0088 \\
\hline SP & 0.001290 & 0.000353 & 3.654390935 & 0.2430 \\
\hline IR & 0.019606 & 0.013242 & 1.480592056 & 0.1594 \\
\hline NPL(-1) & 0.666406 & 0.134786 & 4.944178170 & 0.0002 \\
\hline C & -0.614897 & 0.252165 & -2.43847084 & 0.0277 \\
\hline R-squared & 0.911317 & Adjusted R-squared & 0.869932 \\
\hline F-statistics & 22.02025 & \multicolumn{2}{c}{ Durbin-Watson Stat } & 1.401927 \\
\hline Aut
\end{tabular}

Authors' own calculations. 
The results illustrate that all the variable with the exception of gross domestic product have the positive impact of non-performing ratio. Therefore, a surge in energy crisis, exchange rate, shares' prices, interest rate and previous year's portfolio of nonperforming loan will propagate the non-performing ratio; in contrast an increase in GDP will lower the NPL ratio. The extent to which individual variable influence the dependent variable, energy crisis is prominent with the value 4.8203 of beta coefficient followed by previous years NPL (0.6664) and GDP (-1.0492).

Energy crisis have been a problem in Pakistan since almost a decade till now and have positive impact on NPL which has been proved by our study also. Beta coefficient having probability value 0.0472 indicates that impact of energy crisis on NPL is significant. Energy crisis contribute to NPL amount and ultimately damage the economy through reducing the firms' output and revenue prospects. These findings are consistent with the previous research conducted by Keeton and Morris (1987).

Exchange rate is also an influential factor of NPL, 0.0077890 is minor value of coefficient but $p$-value suggests the significance of this relationship. An increase in domestic exchange rate results in high prices of imported machinery and raw material which lead high production cost of goods and services, consequently reduce the revenue demoting the ability of firms to repay the loans of banking industry. Same results were estimated by Khemraj and Pasha (2009).

High GDP means that economic activities in the country are at boom and ability of individuals and firms to repay the institutional loans is high. Thus, gross domestic product has positive relationship with NPL. Value of coefficient -0.049261 shows $4.9 \%$ reduction in NPL ratio due to a million increase in GDP of Pakistan. As p-value 0.0088 is less than $5 \%$ level of significance, we can conclude that impact of GDP on NPL is significant.

An increase in equity prices also escalate the NPL ratio because when performance of stock market is thriving equity prices tends to be high and individuals and businesses rush to buy the shares rather to repay the loans consequently resulting in an upsurge in NPL. This finding supports the results of previous study conducted by Sarohi and Tariq (2009)

When we consider the impact of interest rate on NPL, we have 0.019606 value of coefficient and $p$-value of 0.1594 , showing a positive relationship between the variables. 
However the impact of interest rate on NPL ratio is insignificant as far as economy of Pakistani is concerned. In economic theory interest rates and loans a valid reason for this positive relationship can be identified that is if interest rate becomes higher and higher, it will be cost effective for individuals and firm owners not to repay the past loans at lower interest rates rather obtaining new ones or rescheduling the past loans at higher interest rates. These results are coherent with the results obtained by Nkusu (2011), Adebola, Yusoff \& Dahalan (2011), Louzis, Vouldis \& Metaxas (2011) and Siddique, Malik \& Shah (2012).

Our study also include previous year's NPL ratio as independent variable to explain the current year's NPL ratio. Results of regression analysis (beta coefficient is 0.666406 and $p$-value is 0.0002 ) shows a powerful and significant impact of lagged NPL ratio on current NPL ratio. Coefficient of determination is $91.13 \%$ displaying the fact that $91.13 \%$ change in current year's NPL ratio is explained the independent variables included in the model. Significance of the model have also been ascertain from the value of $\mathrm{F}$ statistic. The Durbin Watson statistic is 1.401927 (statistics are given in the table-4) indicating a positive autocorrelation in the residuals which weaken the predicting ability of the model. The problem of autocorrelation has also been diagnosed by using the Breuschgodfrey Serial Correlation LM test. White test confirms the absence of Heteroskedasticity in the analysis.

Table 4: OLS Regression Results for Model

\begin{tabular}{cccc}
\hline \multicolumn{4}{l}{ Breusch-godfrey LM Test } \\
\hline F-statistics & Probability & R-squared & Probability \\
\hline 2.012524 & 0.177883 & 2.890740 & 0.089090 \\
\hline \multicolumn{2}{l}{ Ramsey RESET Test } & & \\
\hline F-statistics & Probability & Log Likelihood Ratio & Probability \\
\hline 0.427397 & 0.523862 & 0.691648 & 0.405604 \\
\hline White Test & & & \\
\hline F-statistics & Probability & R-squared & Probability \\
\hline 0.750450 & 0.695053 & 13.05744 & 0.522006 \\
\hline
\end{tabular}

Authors' own calculations.

\section{CONCLUSIONS AND POLICY IMLICATIONS}

This study is an attempt to analyze the macroeconomic impact on non-performing loans in Pakistan. Ordinary least square (OLS) is used on the time series data after 
checking the stationary properties of the data series to estimate the multiple regression model. Empirical results of the model concluded that all the independent variables such as energy crisis, exchange rate, shares' prices, interest rates and lagged NPL except gross domestic product have positive impact on NPL. All variables have significant impact on NPL while on the other hand impact of shares' prices and interest rates is found to be insignificant. Result of our study are also aligned with the previous studies but on the same time it should also be kept in mind that besides these macroeconomic factors there are many institutional, bank specific and legal and regulatory framework factors which can have a significant influence on NPL.

Our study suggests that government should have some serious policy making regarding new dams and other alternatives of energy production in order to overcome energy crisis. State Bank of Pakistan must have a keen eye on the NPL in the banking sector; it should also amend the prudential regulations for rescheduling the loans. Moreover, banks should also put their efforts to recover the problem loans. Further studies could be done by including the bank and borrower specific factors, saving and other macroeconomic variables in order to highlight the true picture of the story.

\section{REFERENCES}

Abedola, S. S., Wan Yusoff, W. S., \& Dalahan, J. (2011). An ARDL approach to the determinants of nonperforming loans in Islamic banking system in Malaysia. Kuwait Chapter of Arabian Journal of Business and Management Review, 1(1), 20-30.

Ahmad, F., \& Bashir, T. (2013). Explanatory Power of Macroeconomic Variables as Determinants of Non-Performing Loans: Evidence from Pakistan. World Applied Sciences Journal, 22(2), 243-255.

Akhter, S., \& Daly, K. (2009). Bank health in varying macroeconomic conditions: A panel study. International Review of Financial Analysis, 18(5), 285-293.

Asari, F. F. A. H., Muhamad, N. A., Ahmad, W., Latif, N. I. A., Addullah, N., \& Jusoff, K. (2011). An Analysis of Non-Performing Loan, Interest Rate and Inflation Rate Using Stata Software. World Applied Sciences Journal, 12, 41-48.

Badar, M. U. N. I. B., \& Javid, A. Y. (2013). Impact of macroeconomic forces on nonperforming loans: An empirical study of commercial banks in Pakistan. wseas Transactions on Business and Economics, 10(1), 40-48.

Bebczuk, R., \& Sangiácomo, M. (2008). The Determinants of Non-Performing Loan Portfolio in the Argentine Banking System. Ensayos Económicos, 1(51), 83-121. 
Farhan, M., Sattar, A., Chaudhry, A. H., \& Khalil, F. (2012). Economic Determinants of Non-Performing Loans: Perception of Pakistani Bankers. European journal of business and Management, 4(19), 87-99.

Festić, M., Kavkler, A., \& Repina, S. (2011). The macroeconomic sources of systemic risk in the banking sectors of five new EU member states. Journal of Banking \& Finance, 35(2), 310-322.

Ghosh, S. (2007). Does Financial Liberalization Lower Problem Loans in Banks? Economic Notes, 36(2), 171-188.

Govt. of Pakistan (2000). 50 years of Pakistan in Statistics, Federal Bureau of Statistics, Statistical Division.

Govt. of Pakistan (2011). Handbook of Statistics on Pakistan Economy 2010, State Bank of Pakistan.

Govt. of Pakistan (2012-13). Economic Survey of Pakistan, Federal Bureau of Statistics, Statistical Division.

Gujarati, D. N. and Porter, D. C. (2009). Basic Econometrics, 5th Edition.

International Monetary Fund, (2013). International Financial Statistics. IMF, Washington, DC.

Keeton, William and Charles S. Morris (1987). Why Do Banks' Loan Losses Differ? Federal Reserve Bank of Kansas City, Economic Review, May, 3-21.

Khemraj, T., \& Pasha, S. (2009, August). The determinants of non-performing loans: An econometric case study of Guyana. In Caribbean Centre for Banking and Finance Bi-annual Conference on Banking and Finance, St. Augustine, Trinidad.

Louzis, D. P., Vouldis, A. T., \& Metaxas, V. L. (2012). Macroeconomic and bank-specific determinants of non-performing loans in Greece: A comparative study of mortgage, business and consumer loan portfolios.Journal of Banking \& Finance, 36(4), 1012-1027.

Masood, O., \& Aktan, B. (2009). DETERMINANTS OF NON-PERFORMING LOANS: A COMPARATIVE ANALYSIS. ACTUAL PROBLEMS OF ECONOMICS, (102), 251263.

Messai, A. S., \& Jouini, F. (2013). Micro and macro determinants of non-performing loans. International Journal of Economics and Financial Issues, 3(4), 852-860.

Moinescu, B., \& Codirlaşu, A. (2012). Assessing the Sectoral Dynamics of Non-performing Loans: Signs from Financial and Real Economy. Theoretical and Applied Economics, 2(2), 69-80

Nkusu, M. (2011). Nonperforming loans and macro financial vulnerabilities in advanced economies. IMF Working Papers, 1-27.

Sheefeni, J. P. (2015). The Impact of Macroeconomic Determinants on Non-performing Loans in Namibia. International Review of Research in Emerging Markets and the Global Economy (IRREM), 1(4), 612-632.

Shrestha, N. R. (2011). Non-Performing Loans and Stock Prices: A Case of Nepali Commercial Banks. PYC Nepal Journal of Management, 4(1), 92-117 
Sirohi, I. K., \& Tariq, M. (2009). "Has privatization reduced the proportion of NonPerforming Loans and increased bank performance in Pakistan": Muslim Commercial Bank and Allied Bank Limited (Pre-privatization and Post-privatization comparison), Retrieved from www.divaportal.org/smash/get/diva2:300716/ATTACHMENT01

World Bank, (2013). World Development Indicators. World Bank, Washington, DC. 